\title{
STUDY ON THE APPRECIATION OF THE LEVEL OF PHYSICAL CONDITION IN ADULTS
}

\author{
Scurt C.
}

\section{cornelscurt@vahoo.com, Transilvania University of Brașov}

\begin{abstract}
Summary: The research hypothesis is based on the assumption that the factors of the physical condition under evaluation are in accordance with the level of growth and development of the tested subjects. The object of the research is the model of physical condition of the students from the final year of FPEMS. The purpose of the research is the continuous improvement and guidance of the content of the preparatory lessons in order to maintain an optimal level of physical condition, necessary to fulfil the requirements of the school program. The practical value of the research consists in the possibility to elaborate training models, by allowing the specialists to select the most effective factors that influence the level of physical condition.
\end{abstract}

Keywords: tests, physical condition, Eurofit

\section{Introduction}

The physical condition is the capacity to withstand, to successfully cope, both with the possible challenges and with those present in daily life [10].

A translation of the Anglo-Saxon word "physical fitness", the physical condition can be considered as the acquisition by an individual of a level of physical ability that gives them the possibility to perform an exercise, some sport or a constant daily activity.

Fleisman defines physical condition as the individual's ability to succeed in certain classes of activities that require muscle activity $[5,6]$.

Bouchard defines physical condition as the optimal combination of the physical, biological, biochemical, biomechanical characteristics meant to function in a satisfactory way in a muscular activity [2].

Legido considers physical condition as being "an ensemble of organic, anatomical and physiological qualities or conditions that an individual must have in order to be able to perform a certain amount of physical effort in both sporting and daily activities [8].

From the enumeration and analysis of the points of view referring to the physical condition it is considered that while, for the coaches, physical condition is synonymous with the performance, they always want to have as many means and methods as possible to allow a certain level of physical effort, without any negative effect on their health. The teachers select the most suitable 
methods and means for the physical education class, the objective being the physical training of the students in order to achieve competences and abilities and to maintain an optimal state of health.

For Alvarez del Vilar physical condition represents a general concept, being defined as the success of the human body to oppose the unilateral muscular activity that unites the professional activity with other ordinary movements or positions [3].

Merhatova and Macek consider that physical condition results from "the totality of personal conditions that allow an optimal reaction when performing a difficult physical activity, taking into account the influence of external factors" [9].

The Committee of Experts of the Council of Europe considers physical condition to be the ability of the body to carry out daily activities with vigour, without accentuated tiredness, by conserving enough energy to perform free time activities and to deal with unusual situations and emergencies [11].

The identification and description of the components of the physical condition (fitness) is an important topic for specialists in the field. E. Fleishman (1964) quoted by M. Epuran (2005) identifies 9 factors, the tests being performed on the field, without complex equipment: flexibility in extension, dynamic flexibility, explosive force, static force, dynamic force, trunk force, general body balance, general coordination, stamina (cardiovascular endurance) [7]. 
APPENDIX TO RECOMMENDATION No. R(87)9 of the Committee of Ministers on Eurofit physical aptitude test, May 19, 1987.

EUROFIT physical fitness tests

\begin{tabular}{|c|c|c|c|}
\hline \multirow[t]{2}{*}{ Identification data } & NAME SURNAME & Age (years, months) & \\
\hline & & Gender (m/f) & \\
\hline \multirow{3}{*}{$\begin{array}{l}\text { Anthropometric } \\
\text { measures }\end{array}$} & & Waist $(\mathrm{cm})$ & \\
\hline & & Weight (kg) & \\
\hline & & $\begin{array}{l}\text { Body fat, five skin folds: biceps, } \\
\text { triceps, sub-scapular, supra-iliac, } \\
\text { maleolar (mm). }\end{array}$ & \\
\hline $\begin{array}{l}\text { Dimension } \\
\text { Tvaluated skills / } \\
\text { competencies, }\end{array}$ & Factor & $\begin{array}{l}\text { EUROFIT test } \\
\text { Evaluation tools }\end{array}$ & \\
\hline $\begin{array}{l}\text { Dardio-respiratory } \\
\text { iresistance } \\
\mathrm{m}\end{array}$ & $\begin{array}{l}\text { Cardio-respiratory } \\
\text { resistance }\end{array}$ & $\begin{array}{l}\text { Endurance shuttle race }(\mathrm{min} / \mathrm{sec}) \text {, } \\
\text { Ergometric bike test }(\mathrm{min} / \mathrm{sec}) \text {, }\end{array}$ & 9 \\
\hline \multirow{2}{*}{$\begin{array}{l}\text { Eorce } \\
\text { n } \\
\text { s }\end{array}$} & Static force & Manual dynamometry (kg), & 5 \\
\hline & Explosive force & $\begin{array}{l}\text { Long jump without momentum } \\
(\mathrm{cm}) \text {, }\end{array}$ & 4 \\
\hline \multirow{2}{*}{$\begin{array}{l}\text { Muscular endurance } \\
\text { u } \\
\text { i }\end{array}$} & Functional force & Suspended bent arm (sec), & 7 \\
\hline & Strength of the trunk & $\begin{array}{l}\text { Lifting from the sitting position } \\
\text { (no / 30sec), }\end{array}$ & 6 \\
\hline \multirow{2}{*}{$\begin{array}{l}\text { Speed } \\
\text { Ș } \\
\end{array}$} & Speed of coordination & Race 10 X 5m (sec) & 8 \\
\hline & Member speed & Hitting the plates (sec), & 2 \\
\hline Flexibility & Flexibility & $\begin{array}{l}\text { Torso flexion forward, } \\
\text { in the sitting position }(\mathrm{cm}) \text {, }\end{array}$ & 3 \\
\hline balance & General balance & Flamingo balance test (sec). & 1 \\
\hline
\end{tabular}

a

Table 1. Factors that influence the level of physical condition related to the Eurofit test battery [Adam et al., 1992, Eurofit].

\section{Material and method}

The program includes percentile masses on the Eurofit test battery, for both sexes, as well as the introduction of new tests and test batteries, and the modification of the existing ones.

The test battery contains 10 tests for the evaluation of 9 (nine) factors that influence the level of the physical condition, all of them measure the level of the physical condition related to the motor range (coordination, power, skill, speed, balance), 5 (five) of them being directly related to the health status [Adam et al., 1992, Eurofit]. 
Along with the motor tests, the battery of tests includes measurements of anthropometric indicators and data for the identification of those tested.

The statistical-mathematical indicators that were used in the analysis of the data obtained by measurement were: ${ }^{-} \mathrm{X}$ - arithmetic average, $\sigma$-standard deviation, $\mathrm{W}$-amplitude.

The measurement was performed throughout the research to determine the level of capabilities, factors and evaluation tools as follows:

General balance $=$ FLAMINGO balance test

Speed of repetition in the upper limbs = reaching the circles,

Flexibility/ mobility = while sitting, outstretching hands,

Lower limb explosive force $=$ long jump without momentum,

Static force upper limb = dynamometry of upper limb,

Abdominal muscle strength and resistance $=$ repeated returning lifting of the trunk

Strength and muscular strength in the arms and hands = keeping the arms bent from hanging to a fixed bar,

Travel speed, speed $=$ RACE $10 X 5 \mathrm{~m}$

Cardio-respiratory endurance $=$ RACE $12 X 40 \mathrm{~m}$.

\section{Research results}

By applying the specific balance assessment tools, when testing Eurofit, it results in an arithmetic average of $3.40 \mathrm{sec}$, a number of 5 subjects have values above average and 15 subjects have values below average and the amplitude has the value of $10 \mathrm{sec}$ (Table 2, Graph 1).

When testing the speed of repetition of the upper limbs, touching the circles, the value is 8.07 sec, due to the values of $0 \mathrm{sec}$ of two subjects (7 and 10), (Table 2, Graph 2).

When testing the sitting mobility, outstretching hands, the arithmetic average of $5.60 \mathrm{~cm}$ has lower values in 8 subjects while 12 subjects have higher values, at an amplitude level of $47 \mathrm{~cm}$. which is influenced by negative values $(4,9,12,17,19)$ (Table 2, Graph 3).

Testing to determine the level of explosive force at the level of the lower limbs, the long jump without momentum has an average value of $2.27 \mathrm{~m}$, the amplitude being $50 \mathrm{~cm}$ (Table 2, Graph $4)$.

The strength of the palm flexors tested by means of the dynamometer has average values of $49.85 \mathrm{~kg} / \mathrm{f}, 9$ subjects above average values, and 11 subjects have values above average, the amplitude being $36 \mathrm{~kg} / \mathrm{f}$. (Table 2, Graph 5). 
The lifting of the trunk from dorsal lying in 30 seconds has average values of 30.55 repetitions, of which 9 subjects have values above the average, while 11 subjects have values below the arithmetic mean, the amplitude being 18 (Table 2, Graph 6).

For testing the determination of the strength and resistance at the level of arms and shoulders the hanging test with the arms bent was used, the arithmetic mean is $52.80 \mathrm{~min} / \mathrm{sec}, 7 \mathrm{subjects}$ have values above the mean, while 13 subjects have values below the arithmetic mean value of the amplitude being $82 \mathrm{sec}$ (Table 2, Graph 7).

TABLE 2 TEST RESULTS

\begin{tabular}{|c|c|c|c|c|c|c|c|c|c|c|c|c|c|c|c|c|c|c|c|c|}
\hline \multirow[b]{2}{*}{$a$} & \multirow[t]{2}{*}{$\begin{array}{l}\text { N.P.O } \\
x\end{array}$} & \multicolumn{2}{|c|}{$\begin{array}{c}\text { FLA-MINGO } \\
\text { BALANCE } \\
\text { (no. of points)a }\end{array}$} & \multicolumn{2}{|c|}{$\begin{array}{c}\text { TOUCH } \\
\text { CIRCLES } \\
\text { ( } \\
\text { (sec/25cyclesa }\end{array}$} & \multicolumn{2}{|c|}{$\begin{array}{l}\text { STRETCH } \\
\text { HANDS } \\
\text { f } \\
-(\mathrm{cm}+,--) \mathrm{d}\end{array}$} & \multicolumn{2}{|c|}{$\begin{array}{l}\text { LONG-JUMP- } \\
\text { WITHOUT- } \\
\text { MOMENTUM } \\
(\mathrm{cm} .) \mathrm{a}\end{array}$} & \multicolumn{2}{|c|}{$\begin{array}{c}\text { STRENGTH } \\
\text { OF-PALM- } \\
\text { FLEXORS } \\
\tau \\
(\mathrm{kg} / \mathrm{f}) \mathrm{a}\end{array}$} & \multicolumn{2}{|c|}{$\begin{array}{l}\text { TRUNK- } \\
\text { LIFTING- } \\
\text { FROM- } \\
\text { DORSAL- } \\
\text { LYING } \\
(\mathrm{nr} / 30 \mathrm{sec} .) \mathrm{a}\end{array}$} & \multicolumn{2}{|c|}{$\begin{array}{l}\text { BENT-ARM- } \\
\text { HANGING } \\
(\mathrm{min} / \mathrm{sec}) \boldsymbol{0}\end{array}$} & \multicolumn{2}{|c|}{$\begin{array}{c}\text { RACE } \\
10 X 5 \mathrm{~m} \\
\text { ๆ } \\
\text { (sec.)a }\end{array}$} & \multicolumn{2}{|c|}{$\begin{array}{c}\text { RACE } \\
24 \mathrm{X} 20 \mathrm{~m} \\
\boldsymbol{\sigma}^{-} \\
(\mathrm{min} / \mathrm{sec} .) \mathrm{o}\end{array}$} & \multirow[t]{2}{*}{ 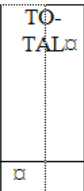 } \\
\hline & & $R \propto$ & PO & $R \propto$ & $\mathrm{PO}$ & $R \propto$ & $\mathrm{PQ}$ & $\mathrm{R} \propto$ & PO & $R \alpha$ & $P \alpha$ & Ra & PO & $R \propto$ & $P Q$ & $R \propto$ & $\mathrm{PQ}$ & $R \propto$ & $P \alpha$ & \\
\hline 1 वर्ष & RAO & $10 x$ & $10 x$ & $9.7 \alpha$ & $40 x$ & $+2 \alpha$ & 200 & $2.30 \%$ & $80 a$ & $60 x$ & $100 \mathrm{a}$ & $33 \alpha$ & $80 x$ & 400 & $60 x$ & $12.2 \mathrm{a}$ & $50 a$ & $2.35 a$ & $50 x$ & 480 \\
\hline 2 की & DMO & $2 \alpha$ & 900 & 10.30 & 200 & $+8 a$ & 500 & $2.30 \mathrm{a}$ & 80 & 540 & $90 \%$ & $22 \alpha$ & $0 x$ & 700 & $100 x$ & $12.2 \mathrm{\alpha}$ & 500 & 2.250 & 70 & 550 \\
\hline 3क्षे & EVo & 30 & $80 x$ & $8.6 a$ & $70 x$ & +60 & $40 x$ & 2.100 & 400 & $38 a$ & 600 & 320 & $70 x$ & 1110 & 1000 & 12.00 & 600 & $2,14 \propto$ & $90 x$ & 590 \\
\hline 4क्ष & RVa & 30 & $80 x$ & $8.2 \alpha$ & $80 a$ & $0, a$ & $0 x$ & $2.10 \mathrm{x}$ & 400 & 400 & $60 x$ & 330 & $80 x$ & 500 & 800 & $12.2 \mathrm{a}$ & 500 & $2.24 \mathrm{\alpha}$ & 700 & 540 \\
\hline 5क्षी & $\mathrm{ADO}$ & $2 \alpha$ & $90 \mathrm{a}$ & 8.00 & 900 & $+10 x$ & 600 & $2.30 \%$ & 800 & $52 \alpha$ & 900 & 300 & $50 \propto$ & 480 & $80 x$ & $12.9 \mathrm{a}$ & $30 a$ & $2.27 \alpha$ & $70 x$ & 640 \\
\hline 6 & $\mathrm{BBO}$ & 100 & $10 x$ & 9.60 & 100 & $+14 \alpha$ & 800 & $2.30 \mathrm{a}$ & 800 & 500 & 800 & $30 x$ & $40 \alpha$ & 490 & $80 x$ & 12.90 & $30 \alpha$ & $2.42 \mathrm{\alpha}$ & 400 & 450 \\
\hline 7 की & I.No & 30 & $10 \%$ & $8.3 \alpha$ & $80 x$ & $+10 \mathrm{a}$ & 60 & 2.300 & $80 \alpha$ & 560 & 900 & 290 & $50 \alpha$ & $33 \alpha$ & $50 x$ & $12.9 \mathrm{a}$ & $30 x$ & 2.250 & $70 x$ & 540 \\
\hline 8की & GGo & $10 x$ & $60 x$ & 00 & 100 & +210 & 100 & 2.200 & $60 x$ & 640 & 100 & 300 & $60 x$ & 540 & $90 x$ & $12.0 \mathrm{~d}$ & $60 a$ & $2.25 \%$ & $70 x$ & 610 \\
\hline 9 d & VMa & $5 a$ & $100 x$ & 9.50 & 400 & 00 & 00 & $2.20 \mathrm{a}$ & $60 x$ & $48 a$ & 700 & 310 & 800 & $43 \alpha$ & 70 & $12.0 \mathrm{a}$ & 600 & 2.250 & $70 a$ & 550 \\
\hline $10 \mathrm{~g}$ & $\mathrm{CO} \alpha$ & 00 & 700 & 00 & 100 & $+7 \alpha$ & 500 & 2.500 & $100 \mathrm{a}$ & 650 & 100 & $33 \alpha$ & $80 x$ & 560 & $90 x$ & $11.8 \mathrm{a}$ & $70 a$ & 2.110 & $100 \%$ & 670 \\
\hline $11 \mathrm{~d}$ & BMo & 40 & $80 x$ & $3.7 \alpha$ & $60 x$ & +50 & $30 x$ & 2.400 & 900 & 600 & 100 & 400 & $50 x$ & $78 a$ & $100 ;$ & $11.4 \mathrm{\alpha}$ & $70 x$ & $2.12 \mathrm{\alpha}$ & 1000 & 660 \\
\hline 129 & LMa & 30 & 100 & 10.20 & $30 x$ & $-5 a$ & $0, a$ & $2.30 x$ & $80 x$ & 300 & 40 & 300 & $60 x$ & 680 & $100 a$ & $12.3 \mathrm{a}$ & $40 ;$ & $2.29 a$ & $60 \alpha$ & 510 \\
\hline 139 & TBO & 00 & 90 & 12.20 & $0 x$ & $+10 a$ & $60 x$ & $2.30 \mathrm{x}$ & 800 & 310 & $40 x$ & 310 & $40 \%$ & $67 \alpha$ & $10 \alpha$ & $12.2 \mathrm{a}$ & 500 & 2.060 & 1000 & $470 a$ \\
\hline 149 & BRo & 2 & 900 & $8.7 \alpha$ & $60 x$ & +60 & $40 x$ & $2.00 x$ & 200 & 290 & $40 x$ & $29 a$ & $30 \alpha$ & 290 & $40 x$ & 12.60 & 400 & 2.250 & 700 & $430 a$ \\
\hline 159 & CPo & $2 \alpha$ & $80 \%$ & $9.2 \alpha$ & 500 & $+10 a$ & 600 & $2.50 \mathrm{a}$ & $100 \mathrm{x}$ & $60 x$ & 100 & 280 & $50 \alpha$ & 450 & $70 x$ & $13.6 \mathrm{a}$ & 200 & $2.32 \alpha$ & $60 x$ & 590 \\
\hline 169 & $\mathrm{TCO}$ & 30 & $80 \%$ & $9.7 \alpha$ & $40 x$ & $+20 \mathrm{a}$ & 100 & 2.400 & 900 & $58 \propto$ & 100 & 300 & $40 a$ & 330 & 500 & $12.5 \mathrm{a}$ & $40 x$ & 2.100 & $100 x$ & 640 \\
\hline $17 \mathrm{~d}$ & AMo & 00 & $10 x$ & $8.4 \alpha$ & $80 \pi$ & $-26 a$ & 00 & 2.100 & $40 \%$ & $58 a$ & 100 & $29 x$ & $40 \%$ & $48 \alpha$ & $80 x$ & $13.1 \mathrm{a}$ & 200 & $2.27 \alpha$ & 700 & $440 a$ \\
\hline 189 & $\mathrm{SBO}$ & 10 & 100 & 10.0 a & 300 & $+12 \alpha$ & 700 & $2.10 x$ & $40 x$ & 440 & 700 & 300 & $50 x$ & 460 & $70 x$ & $12.5 \mathrm{a}$ & $40 ;$ & $2.50 \mathrm{~d}$ & $20 x$ & 490 \\
\hline 190 & NOd & 20 & $90 x$ & 8.10 & $90 x$ & -110 & 00 & $2.30 \alpha$ & 800 & $45 a$ & $70 x$ & 310 & 600 & $40 x$ & 60 & 12.90 & $30 x$ & $2.55 \alpha$ & $10 x$ & $490 \mathrm{a}$ \\
\hline $20 \mathrm{~d}$ & PAO & 30 & $80 x$ & 9.00 & 400 & $+13 a$ & 800 & 2.350 & 900 & $55 a$ & $90 x$ & $30 x$ & $50 x$ & $48 a$ & $80 x$ & 12.50 & $40 x$ & 2.450 & $30 x$ & $580 a$ \\
\hline & $\mathrm{X} \alpha$ & $3.40 \mathrm{a}$ & 70.00 여 & $8.07 \mathrm{a}$ & $46.50 \mathrm{a}$ & $5.60 \mathrm{a}$ & 45.00 여 & $2.27 \mathrm{a}$ & $70.5 \mathrm{a}$ & $49.85 \mathrm{a}$ & $79.5 \mathrm{a}$ & 30.55 여 & $53.0 \mathrm{a}$ & 52.80 o & $73.00 \mathrm{a}$ & $12.37 \mathrm{o}$ & 44.0 여 & $2.28 \circ$ & $66.0 \mathrm{a}$ & $546.0 \mathrm{a}$ \\
\hline & $\sigma \alpha$ & $3.04 a$ & 31.46 명 & $3.10 \mathrm{a}$ & $27.98 a$ & $10.3 \mathrm{a}$ & 32.480 & $0.13 a$ & $22.4 \mathrm{a}$ & $11.05 \mathrm{a}$ & $21.3 \mathrm{a}$ & $3.15 \mathrm{a}$ & $19.2 a$ & $18.35 \mathrm{a}$ & 22.61 영 & $0.43 \mathrm{a}$ & 14.60 & $0.13 a$ & $25.3 \mathrm{a}$ & $73,10 x$ \\
\hline & wo & 100 & $90 x$ & 12.2 a & 900 & $47 x$ & $100 \mathrm{~d}$ & 0.50 & 800 & 360 & 600 & $18 a$ & 800 & 820 & 900 & $1.7 \alpha$ & 500 & $0.49 a$ & 900 & 2400 \\
\hline & & $\mu$ & $a$ & $a$ & $a$ & $a$ & $a$ & $a$ & $a$ & $a$ & $a$ & a & $a$ & $a$ & $a$ & $a$ & $a$ & a & $a$ & $\mathrm{p}$ \\
\hline
\end{tabular}

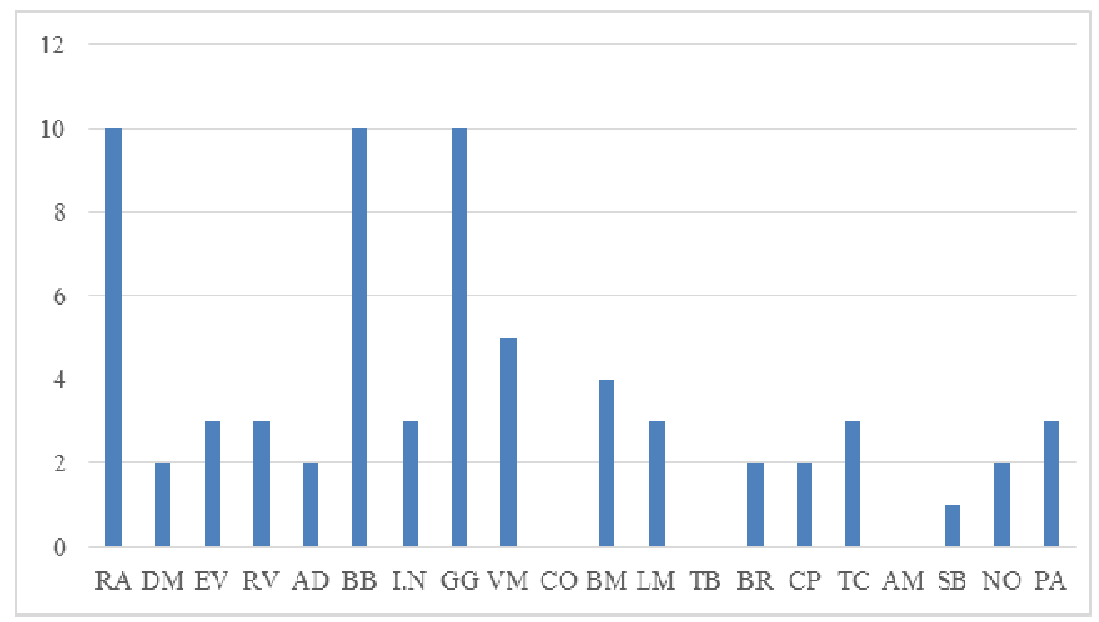

Graph 1. Results of Flamingo balance testing (no/sec) 


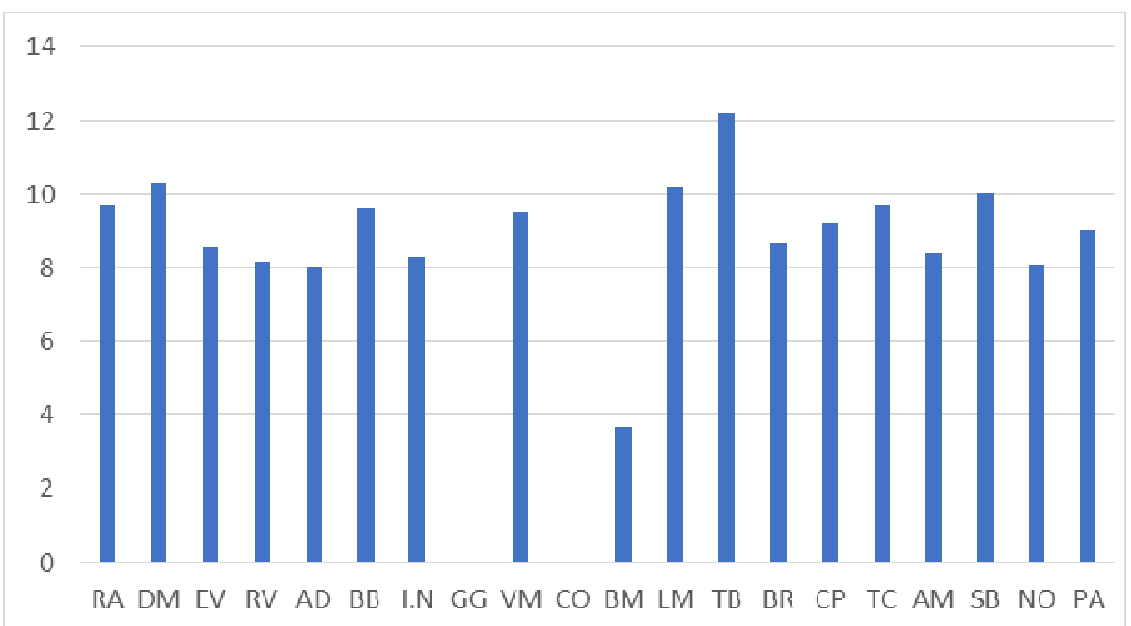

Graph 2. Results when testing touch the circles (sec/25 cycles)

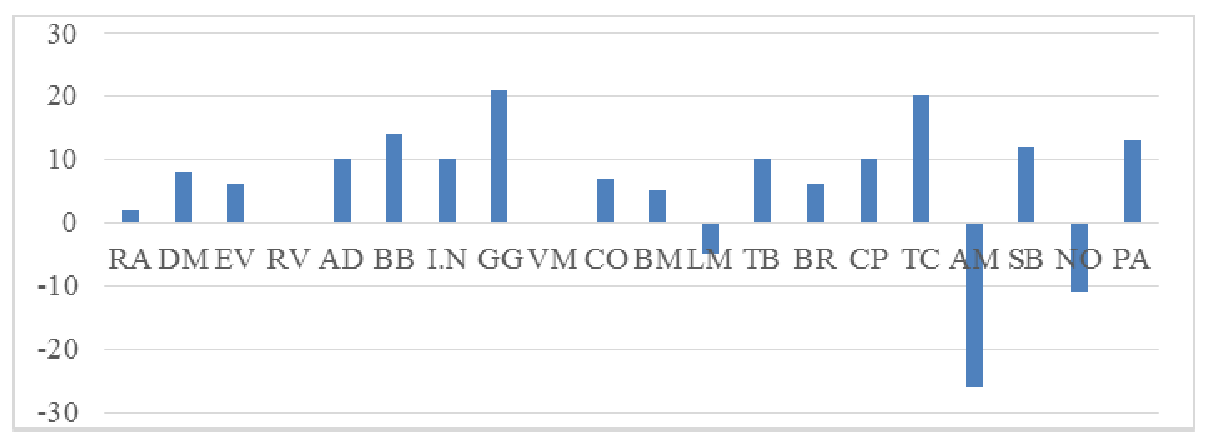

Graph 3. Results when testing stretch the arms (+,-)

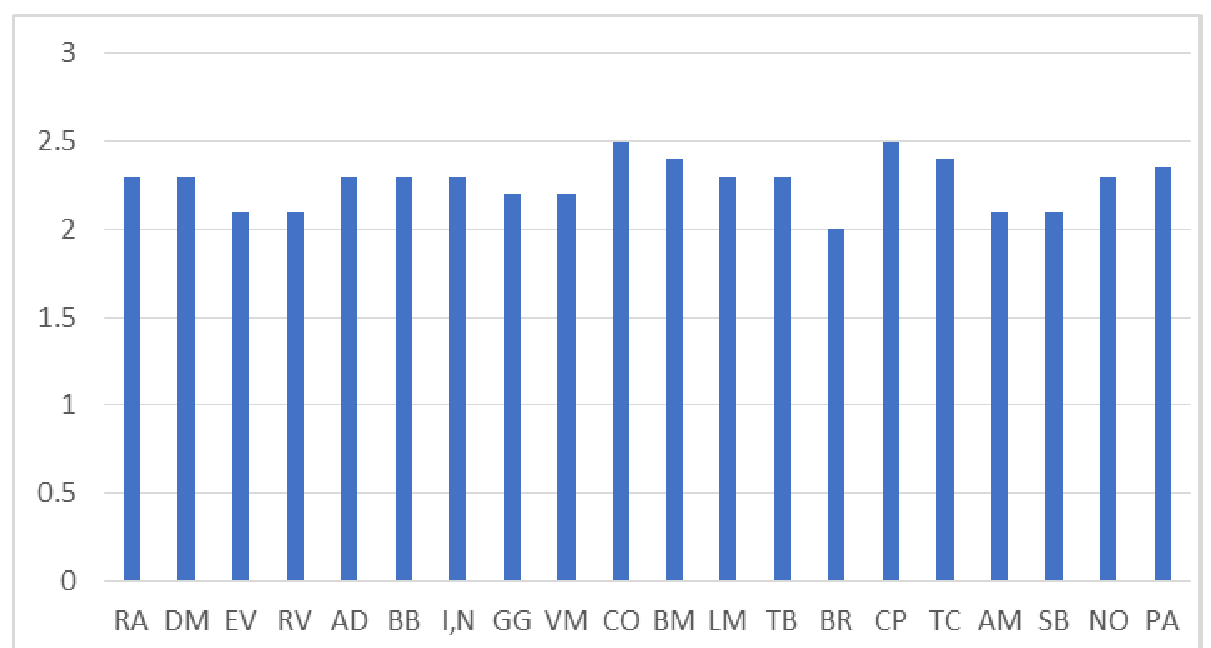

Graph 4. Results when testing long jump without momentum (cm) 


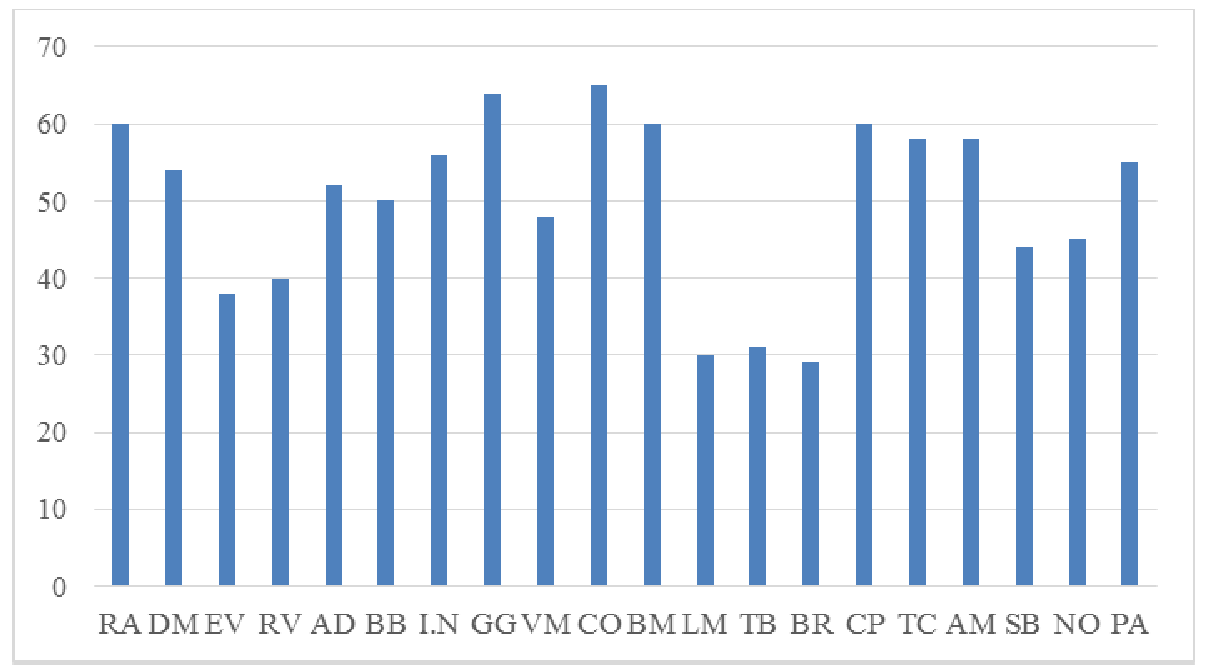

Graph 5. Results when testing the strength of palm flexors (cm)

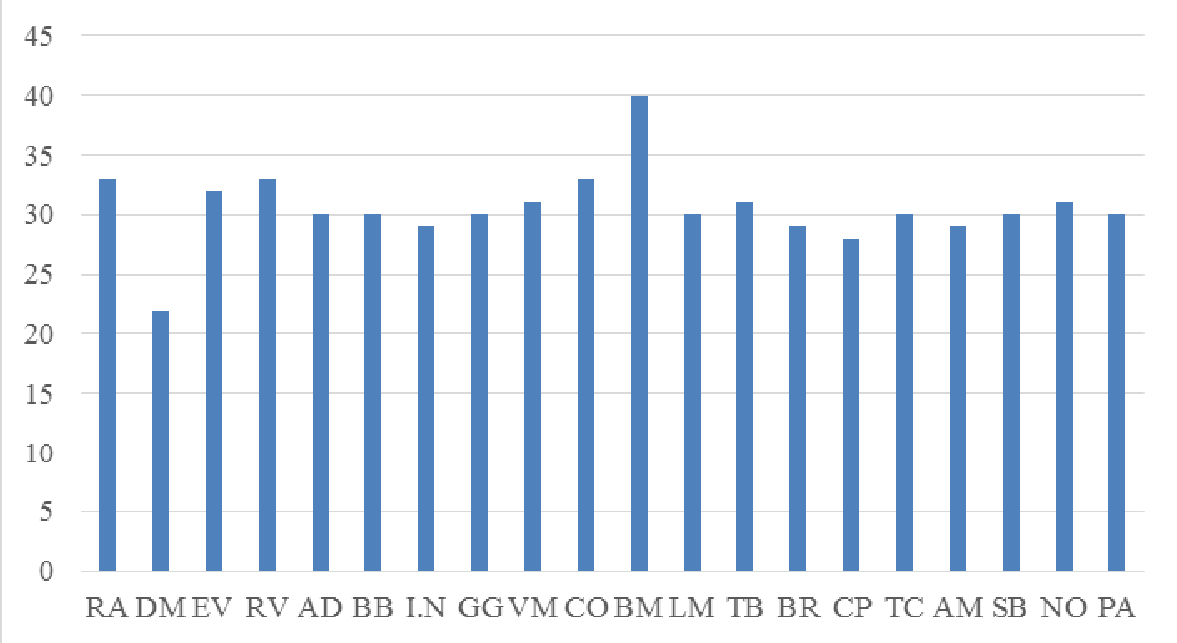

Graph 6. Results when testing trunk lifting from dorsal lying (no./30sec).

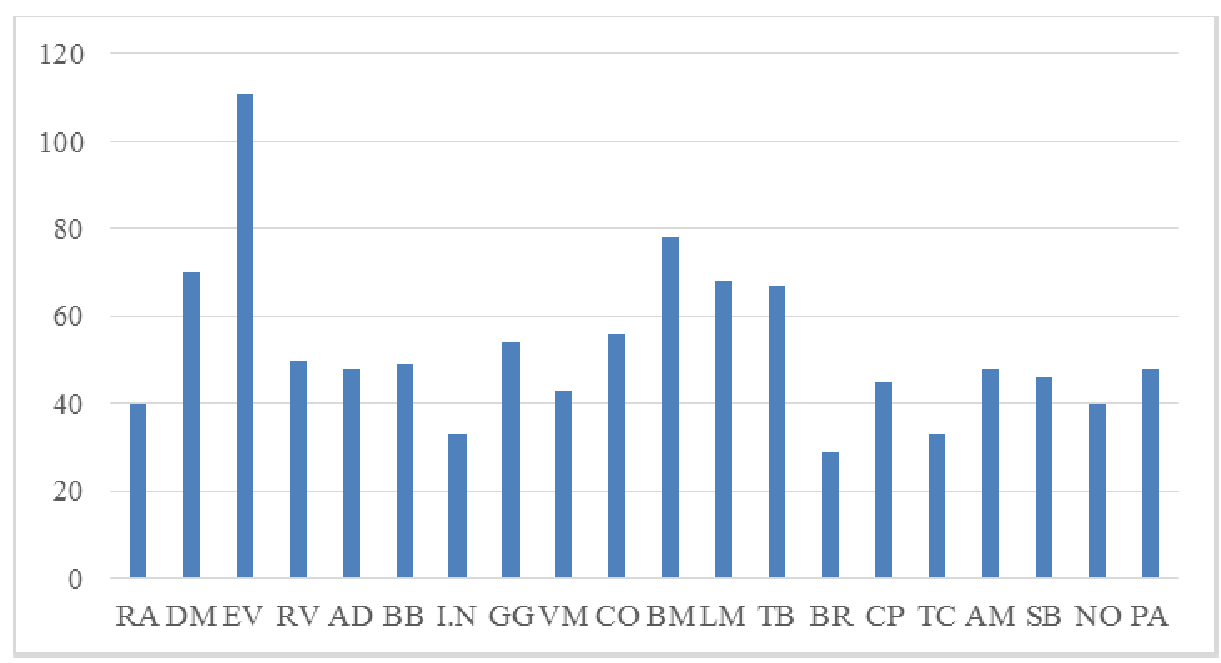

Graph 7. Results when maintaining bent arm hanging ( $\mathrm{min} / \mathrm{sec})$ 


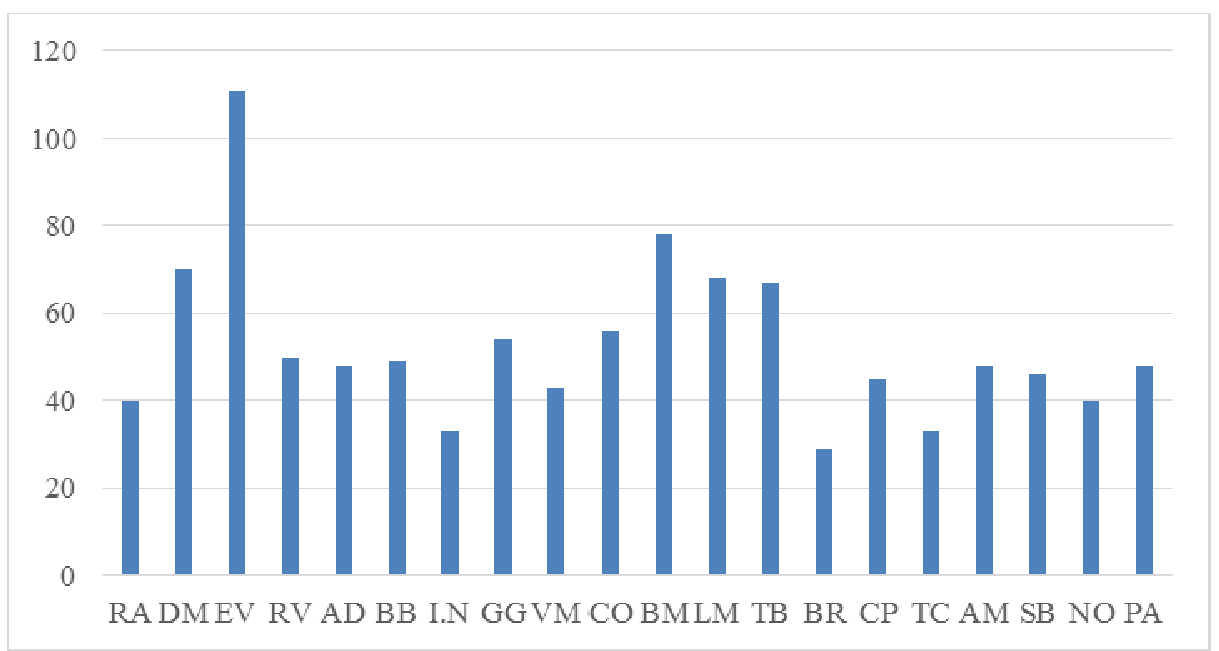

Graph 8. Results when testing race $10 \times 5 \mathrm{~m}(\mathrm{sec})$

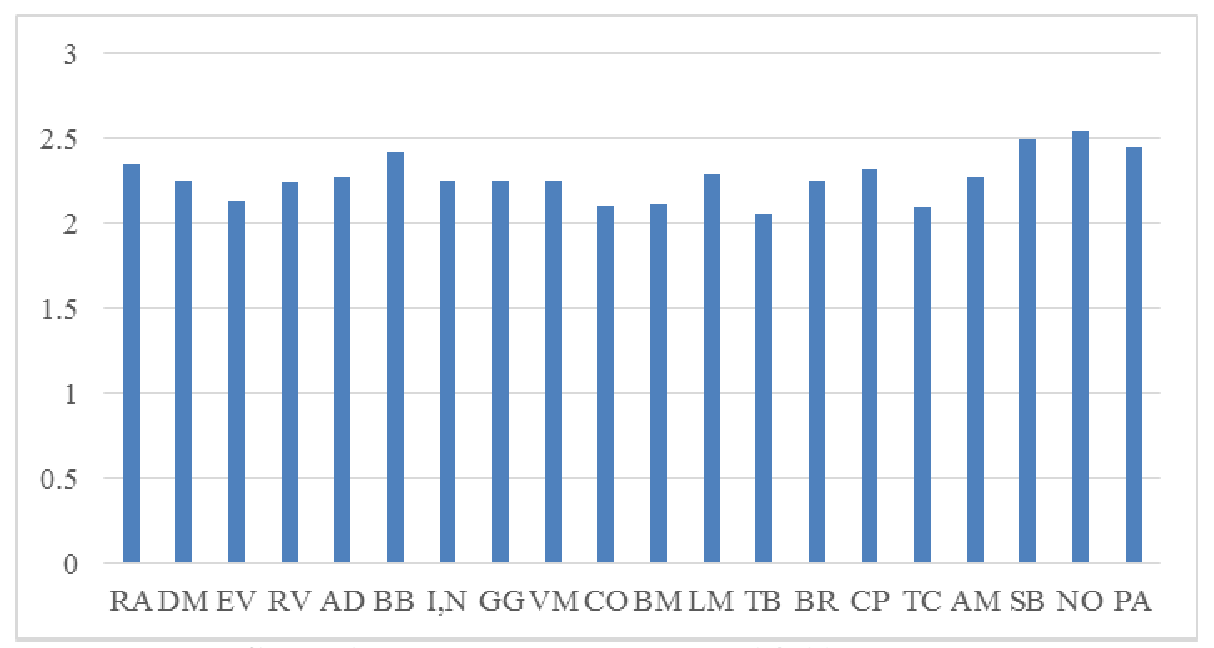

Graph 9. Results when testing race $24 \times 20(\mathrm{~min} / \mathrm{sec})$

Travel speed/ speed was tested by using the $10 \times 5 \mathrm{~m}$ race, the arithmetic mean of $12.37 \mathrm{sec}$ being exceeded by 9 subjects, 11 subjects being below the mean level, the amplitude level being 1.7 sec. (Table 2, Graph 8).

Cardio-respiratory resistance tested by using the $24 \times 20 \mathrm{~m}$ race $(\mathrm{min} / \mathrm{sec})$ gives an average value of $2.28 \mathrm{~min}, 7$ subjects performing above the arithmetic mean level, 13 performing below average level at an amplitude value of $49 \sec$ (Table 9, Graph 9).

\section{Conclusions}

By analyzing the results of the EUROFIT battery test at the level of the subjects, it is noticed that for a number of 5 tests the results are above the average of the tested subjects while the results in 4 tests are below the average.

Given the fact that the average of the subjects with results above the average of the sample for Eurofit battery is $5(1,3,4,5$ and 9), it can be estimated that the tests 6 and 8 are close to these 
values, the physical condition factors evaluated are consistent with the level of growth and development of the tested subjects.

The absence of programs by which young people at this age should be aware of the negative effects of a low level of physical condition, as well as of methods and means of coping with specific requests.

\section{Recommendations}

The assessments regarding the level of physical condition at the level of young people should be correlated with that of the environmental and social factors.

In the situation when it is found out that a part of the young people do not meet the imposed requests, they will be integrated into appropriate training groups in order to improve the level of physical condition.

In order to achieve objective results as well as for an optimal level of physical condition, the tests will be performed and communicated to the tested ones twice a year.

\section{REFERENCES}

1. Adam și colab.,-. Dimensiui și factori care influențează nivelul condiției fizice relaționați cu bateria de teste Eurofit, 1992.

2. Bouchard D, Shephard RJ, Stephens T, Sutton JR, Mc Pherson BD. (Eds.).Exercise, Fitness and Health: A Consensus of Current Knowledge. 1990. Champain, III: Human Kinetics.

3. Carlos Alvarez del Villar- La preparación física basada en el atletismo ISBN $10: 8430088288$ /ISBN 13: 9788430088287 Published by Gymnos, 1983.

4. $\quad$ Eurofit, testes of Physical Tests fitness, 2end Edition Strasbourg, 1993.

5. Epuran, M., Metodologia cercetării activităților corporale, Ed. a II-a, București: FEST, 2005.

6. Fleishman, Edvin,- The structure and measurement of physical fitness 1964.

7. Fleishman, EA (1964) Ce măsoară testul de fitness fizic? O revizuire a cercetărilor anterioare. În: Cliffs, NJ, Ed., Structura și măsurarea condițiilor fizice, Prentice-Hall, Inc., Englewood, 27-37.

8. Legido, M, - Endurance in Sport editat de R. J. Shephard, P.-O. Astrand 1996.

9. Merhautova-Physical Activity: Human Growth and Development editat de G Rarick.1967.

10. Michael E. Lamb. . E -Child Development Vol. 49, No. 4 (Dec., 1978), pp. 1189-1196Published by: Wiley on behalf of the Society for Research in Child Development DOI: 10.2307/1128759 https://www.jstor.org/stable/1128759 Page Count: 8.

11. Ulrich, C.,-Măsurarea deprinderilor motrice 2000 